\title{
Siew New Disease Reports \\ First report of Iris yellow spot virus infecting onion in the Pichincha and Tungurahua provinces of Ecuador
}

\author{
Y. Sivaprasad ${ }^{1,2}$, P. Garrido ${ }^{1}$, K. Mendez ${ }^{1}$, A. Garrido ${ }^{1}$ and L. Ramos ${ }^{1}$ \\ ${ }^{1}$ Ecuadorian Agency for Quality Assurance in Agriculture, AGROCALIDAD, Av. Interoceánica km 14 1/2, 170184 Tumbaco, \\ Ecuador; ${ }^{2}$ Programa Prometeo, Secretaría Nacional de Educación Superior, Ciencia, Tecnología e Innovación (SENESCYT), \\ Quito, Ecuador
}

*E-mail: yeturusivaprasad@gmail.com

Received: 27 Feb 2016. Published: 19 Apr 2016. Keywords: Allium cepa, DAS-ELISA, RT-PCR

Onion (Allium cepa) is one of the most important vegetable crops and is widely cultivated throughout the world. In Ecuador onion is grown on an area of 16,000 ha with a production of 103,316 tonnes (Ministerio de Agricultura, Ganadería, Acuacultura y Pesca, 2012). Iris yellow spot virus (IYSV) was first reported in Idaho, United States of America in 1993 and has since spread to many other onion-producing areas in the world (Gent et al., 2006). IYSV is an emerging virus and belongs to the family Bunyaviridae, genus Tospovirus. IYSV infects monocotyledonous and dicotyledonous plants (Kritzman et al., 2000) and can be transmitted by mechanical inoculation and by Thrips tabaci in a persistent manner (Cortêz et al., 1998). During April 2015, straw-coloured, irregularly shaped, chlorotic or necrotic lesions on leaves were observed (Fig. 1) in two onion fields, one in the province of Pichincha and the other in Tungurahua in Ecuador. The disease incidence observed in both fields was $10-15 \%$ and plants were heavily infested with thrips. Based on symptomatology, a tospovirus infection was suspected.

The presence of the IYSV in diseased leaves of twenty plants was initially confirmed by DAS-ELISA using IYSV polyclonal antibodies (Agdia, USA). Total RNA was isolated from leaf tissues of ten onion plants (five from each province). RT-PCR was done using IYSV-specific primers designed to detect sequences flanking the nucleocapsid-coding region on the S-segment (Robène-Soustrade et al., 2006) and resulted in a c. 890 bp amplicon. One product amplified from a sample from each province was sequenced (Macrogen, Seoul, Korea) and deposited in GenBank with Accession Nos. KP772267 (Onion-IYSV: Pichincha-Ecuador) and KT207939 (Onion-IYSV: Tungurahua-Ecuador). Sequence analysis using BioEdit v. 7.05 (Hall, 1999), of isolates from the present study compared with previously reported IYSV isolates showed a maximum of 99.1\% nucleotide and $99 \%$ amino acid identities in the coat protein coding region. A phylogenetic tree constructed with nucleotide sequences of the coat protein region using MEGA v. 4.1 showed that the Onion-IYSV: Pichincha-Ecuador isolate was closely related to IYSV isolates from Mexico (JX946658), Canada (EU287943), New Zealand (EU477515), USA (DQ233468 and JQ973067), Guatemala (DQ838590), Japan

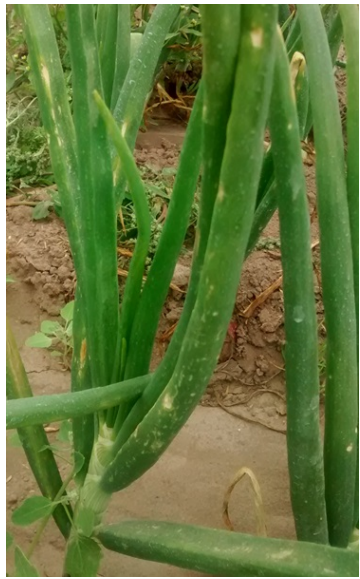

Figure 1

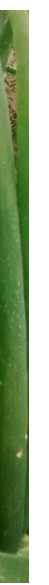

To cite this report: Sivaprasad Y, Garrido P, Mendez K, Garrido A, Ramos L, 2016. First report of Iris yellow spot virus infecting onion in the Pichincha and Tungurahua provinces of Ecuador. New Disease Reports 33, 16. http://dx.doi.org/10.5197/j.2044-0588.2016.033.016

(c) 2016 The Authors

This report was published on-line at www.ndrs.org.uk where high quality versions of the figures can be found.

(AB871447), Bosnia \& Herzegovina (KF733020), Chile (DQ150107) and Spain (EF427447), and formed one cluster. Whereas, the Onion-IYSV: Tungurahua-Ecuador isolate was closely related to IYSV isolates from India (DQ270004), Greece (FJ785835), Australia (AY556424 and AY345227) and Japan (AB871438), forming a separate cluster (Fig. 2). To the best of our knowledge this is the first report of the natural occurrence of IYSV in onion in Ecuador.

\section{References}

Cortêz I, Livieratos IC, Derks A, Peters D, Kormelink R, 1998. Molecular and serological characterization of iris yellow spot virus, a new and distinct tospovirus species. Phytopathology 88, 1276-1282.

http://dx.doi.org/10.1084/PHYTO.1998.88.12.1276

Gent DH, du Toit LJ, Fichtner SF, Mohan SK, Pappu HR, Schwartz HF, 2006. Iris yellow spot virus: an emerging threat to onion bulb and seed production. Plant Disease 90, 1468-1480. http://dx.doi.org/10.1094/PD-90-1468

Hall TA, 1999. BioEdit: a user-friendly biological sequence alignment editor and analysis program for Windows 95/98/NT. Nucleic Acids Symposium Series 41, 95-98.

Kritzman A, Beckelman H, Alexandrov S, Cohen J, Lampel M, Zeidan M, Raccah B, Gera A, 2000. Lisianthus leaf necrosis: a new disease of lisianthus caused by Iris yellow spot virus. Plant Disease 84, 1185-1189. http://dx.doi.org/10.1094/PDIS.2000.84.11.1185

Ministerio de Agricultura, Ganadería, Acuacultura y Pesca, 2015. Boletín situacional cebolla colorada. http://sinagap.agricultura.gob.ec/phocadownlo adpap/cultivo/2014/gboletin-situacional-cebollacolorada-2014-actualizado.pdf. (Accessed 27 February 2016.)

Robène-Soustrade I, Hostachy B, Roux-Cuvelier M, Minatchy J, Hédont M, Pallas R, Couteau A, Cassam N, Wuster G, 2006. First report of Iris yellow spot virus in onion bulb- and seed-production fields in Réunion Island. Plant Pathology 55, 288. http://dx.doi.org/10.1111/j.1365-3059.2005.01262.x

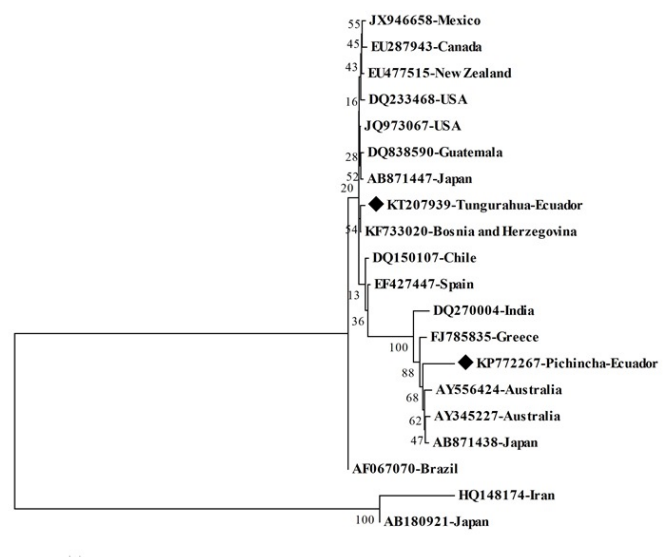

Figure 2 